EDUKACJA MIĘDZYKULTUROWA

2018, nr 1 (8)

ISSN 2299-4106

DOI: $10.15804 / \mathrm{em} .2018 .01 .16$

\title{
Kazimierz Kossak-Główczewski, Adela Kożyczkowska (red.): Wielokulturowość: między edukacją regionalnq a edukacją międzykulturową. Dylematy i konteksty tożsamościowe. Kraków 2015, Oficyna Wydawnicza „Impuls”, ss. 440
}

Książka, którą polecam do przeczytania stanowi zbiór 28 tekstów napisanych przez 31 autorów. Zaproponowany przez redaktorów tytuł pracy zbiorowej dobrze obejmuje zamieszczone w niej teksty. Gdyby z tytułu usunąć słowo „między” i spójnik »a« otrzymalibyśmy gotowe słowa kluczowe. Jednakże to „między” odgrywa tu szczególną rolę, gdyż wskazuje na związki i relacje między edukacją regionalną a edukacją międzykulturową, nie jako przeciwstawienie, lecz wspólne elementy należące do wielokulturowości. Wnikliwe wczytanie się przez Redaktorów w ich treść pozwoliło na uchwycenie celów, idei, implikacji i przesłań, jakie niosą ze sobą poszczególne opracowania. Na strukturę książki składają się: Słowo wstępne, teksty pomieszczone w 4 częściach (Część I. Tymczasowe rozpoznania, Część II. Edukacja: od doświadczania świata do (re)konstrukcji tożsamości, Część III. Język - edukacja - zmagania o tożsamość - III, Część IV (Tymczasowe) propozycje edukacyjne). Układ tekstów jest przemyślany, logiczny i podporządkowany przyjętej koncepcji. Ważne jest też wzajemne powiązanie tekstów w ramach poszczególnych części oraz nadanie im trafnych i interesujących tytułów (na tle dość schematycznych tytułów rozdziałów w wielu pracach zbiorowych), których sens wyjaśnia Adela Kożyczkowska we Słowie wstępnym (s.9-16). Wskazuje na zasadnicze wątki w opracowaniach poszczególnych autorów. Dobrze wprowadza Czytelnika w cele opracowania pisząc: „Ta książka jest jedną z możliwych map. Skonstruowano ją przez (subiektywne redaktorskie) odczytania (wielo)kulturowości z autorskich, indywidualnych rozumień świata. Sens tej mapy wynika wprost z odczytanej logiki pulsowania kategorii „tożsamość” w tekstach autorskich. Autorzy w poszczególnych artykułach wspót(u)tworzyli rozumienie wielokulturowości, której horyzonty sq wytyczane przez tożsamość, edukację międzykulturowa i edukację regionalną" (s.10).

Wybrane przez Redaktorów prace mają zróżnicowany charakter: ze względu na podejmowane tematy, rozmiar, obszar badań, reprezentowaną dyscyplinę naukową, posiadane doświadczenie w zakresie tej tematyki.

Autorami są w dużej mierze uznani i cenieni specjaliści w zakresie edukacji wielo- i międzykulturowej oraz regionalnej. W części autorami prac są znakomici nauczyciele praktycy, którzy popularyzują określone formy organizacyjne oraz osiągnięcia szkół, w zakresie interesującej problematyki. Ich prace wzbogacają 
książkę i pozwalają na konstatację, że idee edukacji regionalnej i wielokulturowości nie należą tylko do sfery rozważań naukowych, ale są praktykowane w polskiej szkole w kraju i poza granicami Polski. Niezwykle wartościowe są tu doniesienia $\mathrm{z}$ realizowanych projektów edukacyjnych dotyczących podjętej tu problematyki. Tom tworzy spójną całość a jego wartość podnosi interdyscyplinarny charakter, gdyż kwestie stanowiące temat opracowania są podejmowane z perspektywy wielu dyscyplin naukowych a także w odniesieniu do różnych regionów Polski z odwołaniami do przykładów zagranicznych.

Monografia pojawiła się $\mathrm{w}$ momencie wzrostu zainteresowania problematyką regionalizmu i wielokulturowości w naszym społeczeństwie, nie tylko w kręgach pedagogów, socjologów, ale także polityków. Można to tłumaczyć naszym wejściem do UE i funkcjonowaniem w jej strukturach, które wymaga podejścia wielokulturowego z jednej strony i krytyką polityki państw uwzględniających wielokulturowość w odniesieniu do uchodźców.

$\mathrm{Z}$ racji obszerności pracy tu sygnalizuję jedynie zawartość poszczególnych części książki.

\section{Część pierwsza. Tymczasowe rozpoznania}

Część pierwszą otwierają wartościowe i krytyczne rozważania Kazimierza Kossaka-Główczewskiego (Edukacja etniczna i regionalna szansa reinhabitacji. Od wielokulturowej ku międzykulturowej edukacji regionalnej, s. 19-31) związane z rolą edukacji etnicznej i regionalnej w kontekście możliwości innego odczytania tożsamości. Stawia istotne pytania dotyczące potrzeby zmian w edukacji regionalnej, tak aby nabrała ona innego wymiaru i prowadziła jej uczestników do przebudowy tożsamości.

Dla tej części, jak i dla całej książki, ważny jest tekst autorstwa Wiktora Rabczuka (Polityczne i prawne aspekty edukacji międzykulturowej i dialogu międzykulturowego, s.33-49). Tekst przygotowany przez znawcę międzynarodowych aspektów polityki oświatowej koncentruje się na uregulowaniach prawnych edukacji międzykulturowej. Autor dokonał przeglądu najważniejszych aktów prawnych, których znajomość jest potrzebna nauczycielom a także politykom, działaczom kulturalnym, aby budowaniu społeczeństwa zróżnicowanego kulturowo mieli świadomość prawną. Dwa kolejne teksty w tej części związane są z kaszubskością. Adela Kożyczkowska (Od praktyki do teorii edukacji regionalnej. Casus kaszubskości, s. 51-83) w swoim obszernym opracowaniu stwarza Czytelnikowi okazję do poznania uwarunkowań kształtowania się tożsamości kaszubskiej po II wojnie światowej, a zwłaszcza w nowych warunkach po roku 1990, jak budowano i wdrażano ideę edukacji regionalnej, aż po próby poszukiwania teorii edukacji regionalnej jako elemencie edukacji międzykulturowej. Daje dobry obraz działań, które rozbudziły świadomość potrzebę budowania świadomości regionalnej. 
Wartościowe opracowanie, wzbogacone o selektywną, dobrze dobraną literaturę przedmiotu rozważań.

Wątek tożsamości został poszerzony w interesującym przeglądzie koncepcji i badań nad tożsamością Kaszubów Moniki Mazurek - Janosik (Współczesna tożsamość kaszubska, s. 85-100). Autorka stara się odpowiedzieć na pytanie: Jak na tożsamość współczesnych mieszkańców Kaszub oddziałuje : język, przestrzeń-miejsce-terytorium, pochodzenie. Syntetyczne i bardzo kompetentne spojrzenie na problemy tożsamości w globalizującym się świecie.

Część pierwszą, jak ją określają redaktorzy „rzeczywistością zatrzymaną”, zamykają rozważania o charakterze uniwersalnym Ireny Kotowicz-Borowy (Znaczenie edukacji regionalnej dla zachowania tożsamości i dziedzictwa kulturowego, s. 101-110), która wskazuje na szereg działań jednostek, grup, stowarzyszeń w różnych regionach na rzecz edukacji regionalnej, które są zarazem dowodem wysokiego stopnia świadomości i rozumienia roli edukacji regionalnej dla zachowania zarówno tożsamości jak i dziedzictwa kulturowego.

\section{Część druga. Edukacja: od doświadczania świata do (re)kontrukcji tożsamości} Składają się na nią zróżnicowane tematycznie opracowania, które łączy element doświadczanych uwarunkowań wpływających na tożsamość, poczynając od edukacji etnicznej szkolnej i pozaszkolnej poprzez stowarzyszenia etniczne, wyznaniowe, kulturalno-oświatowe, po stosunek do innych. Część II otwiera tekst Małgorzaty Stopikowskiej (Szkolnictwo polskiej mniejszości narodowej na Białorusi. Osiagnięcia - tendencje - oczekiwania, s. 113-129). Wartościowe i interesujące opracowanie mówiące o problemach szkolnictwa dla polskiej mniejszości narodowej na Białorusi, które powstało dopiero pod koniec lat osiemdziesiątych ubiegłego wieku. Przedstawia stan i formy organizacyjne polskiego szkolnictwa i nauczania języka polskiego na Białorusi oraz trudne problemy, na jakie napotykają organizatorzy polskiej edukacji, nauczyciele i rodzice po roku 2005. Osoby zainteresowane sprawami Polaków na Białorusi znajdą wiele cennych informacji zarówno w tekście, jak i w przypisach oraz bibliografii. Natomiast Lidia Burzyńska-Wentland (Determinanty egzogenne $i$ endogenne wptywajace na kondycję $i$ jakość pracy kulturalno-oświatowej zwiazków i stowarzyszeń mniejszościowych w województwie pomorskim, s. 131-151) zajęła się kondycją związków i stowarzyszeń mniejszościowych. Dzięki wnikliwej analizie konsekwencji regulacji prawnych dla życia organizacyjnego i kulturalnego mniejszości narodowych i etnicznych oraz przeprowadzonym wywiadom z liderami stowarzyszeń mniejszościowych funkcjonujących w woj. pomorskim uzyskaliśmy w miarę pełny obraz ich działalności na tle ogólnopolskim.

W opracowaniu dobrze zarysowano czynniki wpływające na jakość i rozmiary ich działalności. Trudności na jakie napotykają związki mniejszościowe w woj. po- 
morskim są podobne do całego kraju. Długo oczekiwana ustawa o mniejszościach narodowych i etnicznych oraz języku regionalnym z 2005 roku nie rozwiązała niestety wielu problemów stowarzyszeń mniejszości narodowych i etnicznych. Wątek mniejszości narodowych i etnicznych pojawia się także w interesującym studium porównawczym Edwarda Nycza (Wspótczesne autoidentyfikacje mieszkańców pogranicza etniczno-kulturowego, s. 153-176). Autor na podstawie badań terenowych w dwóch miejscowościach woj. opolskiego (Kędzierzyn-Koźle - miasto i gmina Bierawa (wiejska) oraz dwóch miejscowościach woj. śląskiego (Racibórz - miasto, Jankowice - wieś) prezentuje współczesne autoidentyfikacje mieszkańców obszaru pogranicza etniczno-kulturowego oraz analizuje czynniki o niej decydujące.

Większość tekstów zamieszczonych w książce związana jest z tożsamością narodową, etniczna lub regionalną. Opracowanie Tomasza Dariusza Mamesa ( $M a-$ riawici w przestrzeni edukacyjnej: od koherencji ku dyferencjacji (intra)dyskursu nad mniejszościa mariawicką, s.177-195) związane jest z tożsamością religijną. Autor koncentruje się w nim na kwestiach dotyczących edukacji mniejszości wyznaniowej Mariawitów. Pozwala także na poznanie historii kościoła Mariawitów i stereotypów jakie mu towarzyszą. Napisany bardzo kompetentnie i ciekawie.

Autorami dwóch kolejnych tekstów w tej części tomu są nauczyciele związani ze szkołami, w których naucza się języka kaszubskiego. Pierwszy z nich Lucyny Sorn (O edukacji regionalnej - z doświadczeń nauczyciela regionalisty, s.197-200) dotyczy jej doświadczeń z pracy w Zespole Szkół w Mostach k/Gdyni. Jest on ważny dla całości tomu, ze względu na tematykę, gdyż dzięki niemu dowiadujemy się, jak nauczyciele realizują edukację regionalną w środowisku kaszubskim. Autorem drugiego tekstu jest Witold Bobrowski (Głodnica - Cassubia Felix, s. 201-204), współautor pierwszego elementarza kaszubskiego, nauczyciel społecznej szkoły kaszubskiej w Głodnicy. Esej jest zapisem historycznym walki z lokalną biurokracją i niezrozumieniem idei edukacji międzykulturowej, o samodzielne istnienie szkoły pragnącej realizować cele szkoły etnicznej. Warto tu zwrócić uwagę na esej Joanny Szewczyk-Kowalczyk (Codzienność i zdroworozsadkowość wychowania rodzinnego a możliwość jego waloryzacji regionalizmem. Refleksje na marginesie codzienności, s. 205-214). Teza postawiona przez Autorkę, „że działaniu podmiotów tworzących odrębności regionalne szczególne miejsce zajmuje ich wiedza potoczna, dotycząca dnia codziennego, przechowywana i replikowana w rodzinie" (s. 205) jest niezwykle inspirująca z perspektywy naszej codzienności. Analiza różnych kontekstów doświadczenia i myślenia zdroworozsądkowego skłania Autorkę do potrzeby dostrzegania roli rodziny w edukacji regionalnej. Szkoda, że podejście zaprezentowane w opracowaniu nie jest powszechne.

Dobrze się stało, że Redaktorzy włączyli do tomu fragmenty pracy dyplomowej Anny Całko (Repatrianci w zmaganiach z codziennościa. Wybrane aspekty 
badań wtasnych, s. 215-222), będącej interesującym zapisem rekonstruowania, budowania (czasami traumatycznej) nowej tożsamości przez potomków zesłańców polskich do Kazachstanu, którzy powrócili do Polski. Autorka wykazała się dużą wrażliwością na losy repatriantów i umiejętnością analizy zgromadzonego materiału, skupia się w swoich rozważaniach na trudnościach w rekonstruowaniu tożsamości. Refleksje jakie nasuwają się po lekturze tekstu są smutne. Decydenci, którzy nakłaniali repatriantów do powrotu nie zadbali o to, aby warunki życia repatriantów z Kazachstanu były w Polsce znośniejsze, a integracja przebiegała łagodniej.

\section{Część trzecia. Język - edukacja - zmagania o tożsamość}

Część trzecią otwiera tekst Jolanty Tambor (Rola języka w edukacji służacej budowaniu tożsamości na przykładzie Górnego Ślaska, s. 225-231). Jest to wartościowe opracowanie, w którym Autorka koncentruje się na zabiegach części działaczy śląskich na uznaniu gwary śląskiej za język regionalny. Prezentuje pogląd przemawiający za podejściem do tej kwestii, podobnie jak postąpiono w stosunku do regionalnego języka kaszubskiego. Zgadzam się z poglądem Autorki, że przeciwnicy uznania gwary śląskiej za język regionalny kierują się względami politycznymi i ma to związek z próbami zarejestrowania narodowości śląskiej oraz z tym, że szkoła, w której uczy się języka w sposób usystematyzowany, może przyczyniać się do zachowania tożsamości (zapewne to ma Autorka na myśli, gdy pisze o likwidacji polskich szkół na Litwie i na Zaolziu). Sądzę, że nauczanie szkolne śląskiego języka regionalnego wymagałoby jego kodyfikacji, co może być trudne przy wielu odmianach gwary śląskiej. Tekst Autorki skłania do refleksji i dyskusji.

Tekst Nicole Dołowy-Rybińskiej (Nauczanie języków mniejszościowych: meto$d y$, działania, wyzwania. Przykład języka bretońskiego, łużyckiego i kaszubskiego, s. 233-257) stanowi świetne uzupełnienie do opracowania Jolanty Tabor. Kompetentne studium porównawcze uwzględniające kwestię nauczania języków mniejszościowych z wielu perspektyw. Oparte na szerokiej bazie źródłowej. Zgadzam się ze stanowiskiem Autorki, „że celem edukacji mniejszości nie jest wyłącznie zapoznanie dziecka z językiem. Aby język mniejszościowy miał szansę przetrwać, dzieci powinny móc go używać także w sytuacjach pozaszkolnych" (s. 238).

Dwa kolejne teksty w tej części dotyczą nauki języka ojczystego w warunkach funkcjonowania diaspory, w pierwszym przypadku dotyczy mniejszości niemieckiej na Pomorzu. Tekst Anny Szybowicz (Niemieckie szkolnictwo prywatne i nauczanie wędrowne na Pomorzu w latach 1926-1939, s. 259-279) daje obraz funkcjonowania niemieckiego szkolnictwa prywatnego w polskiej części Pomorza w latach 1926-1939. Autorka przedstawia stosunek władz polskich i polskiej polityki oświatowej do szkolnictwa mniejszości narodowych. dostrzega także przyczyny określonych rozwiązań zwłaszcza wobec mniejszości niemieckiej wiążąc je z polityką Rzeszy w stosunku do szkolnictwa polskiego na jej terenie. 
Drugi esej autorstwa Katarzyny Stankiewicz (Kiedy język polski staje się obcym. O nauczaniu języka i kultury polskiej Polaków na Wschodzie, s. 281-292) jest poświęcony zabiegom polskich skupisk na Wschodzie (Białoruś, Rosja, Ukraina, Kazachstan), działaniom na rzecz zachowania polskiego języka i polskiej kultury, problemom na jakie napotykają polskie organizacje i ich liderzy oraz nauczyciele języka polskiego, „ambasadorzy polskości”. Z opracowania dowiadujemy się także, jakie działania podejmowane są przez władze polskie w kraju na rzecz wsparcia nauczycieli pracujących za granicą.

\section{Część czwarta. (Tymczasowe) propozycje edukacyjne}

Część czwartą otwiera opracowanie Aliny Szczurek-Boruty (Od edukacji regionalnej do edukacji międzykulturowej - ku zbliżeniu ludzi i ich kultur, s. 295-314), które dobrze wpisuje się w tytuł tomu. Autorka poświęciła swój tekst pogłębionej analizie drogi prowadzącej od edukacji regionalnej, poprzez wielokulturową do edukacji międzykulturowej, uwzględniając przy tym tradycje każdej ze wspomnianych odmian edukacji. Dobrą egzemplifikacją jest pogranicze Śląska Cieszyńskiego, którego wielokulturowy charakter pozwala na przybliżenie różnych przejawów aktywności prowadzących do zbliżenia ludzi oraz bogatych tradycji funkcjonowania instytucji i stowarzyszeń na obszarze pogranicza czesko-polskiego. Natomiast Aleksandra Kurowska-Susdorf (Edukacja regionalna wsparta na dziecięcym filozofowaniu. Refleksje z pogranicza praktyki, s. 315-324) swoim inspirującym tekstem dobrze wpisuje się praktykę uprawiania edukacji regionalnej. Stara się w nim odpowiedzieć na szereg pytań, za najważniejsze z nich uznaje odpowiedź na pytanie: jak uczyć języka kaszubskiego, aby język prowadził do korzeni, do tożsamości? Jak wykorzystać wartości tkwiące w świecie dziecięcych bajek i fantazji do refleksji do stawiania pytań, do prowadzenia dialogu w drodze, do szukania odpowiedzi na pytanie: kim jestem?

Trójka Autorów: Maria Mendel, Marcin Boryczko, Dorota Jaworska-Matys (Dialog międzykulturowy i polska szkoła, s. 325-347) prezentuje wyniki międzynarodowego projektu poświęconego dialogowi międzykulturowemu (Good Intercultural Dialogue in Schools” - Good ID” - „Dobry dialog międzykulturowy w szkołach". Projekt był realizowany w Danii, Włoszech, Holandii i Polsce. Wyniki przedstawione przez członków zespołu z Uniwersytetu Gdańskiego dotyczą polskiej jego części. Wartościowe opracowanie, dobrze wiążące teorię i praktykę edukacji międzykulturowej, składa się w ujęciu Autorów z czterech części: 1. założenia projektu i jego podstawy naukowe, 2 . oferta programowa dla nauczycieli i studentów, jako efekt badań pilotażowych, 3. Refleksja nad zajęciami realizowanymi w ramach zaproponowanej oferty, 4 . Wnioski dla praktyki szkolnej z realizacji projektu. Krytyczne i twórcze spojrzenie na realizację projektu może stanowić inspirację do podejmowania podobnych działań w innych środowiskach. Pozwala na określenie miejsca polskiej szkoły w budowaniu dialogu międzykulturowego. 
Autorki Anna Kalinowska-Żeleźnik i Anna Lusińska (Edukacja regionalna a media, s. 349-372), odwołując się do teorii komunikacji i komunikowania się, prezentują bardzo kompetentnie role, funkcje edukacyjne telewizji w odniesieniu do edukacji regionalnej oraz możliwości partycypowania telewizji w jej propagowaniu. Odwołują się do przykładów ośrodków telewizyjnych w Gdańsku (TVP Gdańsk, Telewizja Wybrzeże oraz TV Kaszuby) oraz TVP SA, prezentują ich dorobek i programy w tym zakresie. Wiele praktycznych informacji mogą tu zaczerpnąć nauczyciele.

W tomie znajdujemy ponadto dwa oryginalne i cenne opracowania związane z kulturą muzyczną. Są one o tyle ważne, że tematyka ta jest rzadziej podejmowana, ze względu na swoją specyfikę, przy rozważaniach dotyczących edukacji międzykulturowej. Lukę tę w odniesieniu do Kaszub stara się wypełnić Elżbieta Frołowicz (Kultura muzyczna Kaszub w kontekście wybranych problemów edukacji międzykulturowej, s. 373-386), która w swoim studium przedstawia w zarysie historię kultury muzycznej Kaszub oraz współczesny jej stan, a także działalność edukacyjną w zakresie upowszechniania muzyki kaszubskiej. Ludowa muzyka kaszubska jest traktowana jako wartość szczególna w budowaniu tożsamości. Czytelnik znajdzie tu szereg interesujących wskazówek dotyczących rozwoju kultury, w tym kultury muzycznej na Kaszubach. W odniesieniu do muzyki ludowej na Lubelszczyźnie mamy doniesienie Waldemara Frąckiewicza (Szkota Suki Bitgorajskiej - rodzinna inicjatywa muzycznej edukacji regionalnej, s. 387-391) o kultywowaniu muzyki ludowej za sprawą Zbigniewa i Krzysztofa Butrynów, którzy odtworzyli instrument sukę biłgorajską i prowadzą ludowy zespół muzyczny. Dowiadujemy się także o innych działaniach edukacyjnych w zakresie edukacji muzycznej. Ten międzypokoleniowy przekaz kulturowy w rodzinie jest dla Autora gwarantem zachowania tożsamości kulturowej. „Trzeba mieć nadzieję, że instytucja [Szkoła Suki Biłgorajskiej] wyrastająca z osobistych pasji ojca i syna poprzez swój ludzki wymiar będzie nadal działa konstruktywnie" (s. 391).

Ogólniejszy charakter mają rozważania Anny Weroniki Brzezińskiej i Izabeli Czerniejewskiej (Etno-edukacja - pomiędzy myśleniem globalnym a działaniem lokalnym, s. 393-407). Autorki podjęły próbę odczytania pojęcia etno-edukacja w odniesieniu do typów myślenia i postrzegania rzeczywistości nie jako zamkniętego obszaru, lecz jako elementu większej całości, powiązanej z lokalnym działaniem. Właściwe odczytanie wymaga różnych kompetencji, z których jedne są powiązane z kulturą inne z edukacją. Interesującą ilustracją takiego postrzegania procesów i zdarzeń jest sposób interpretacji zjawisk kulturowych na przykładzie cmentarza. „Na przykładzie cmentarza pokazałyśmy różnorodne podejścia do edukacji dotyczącej dziedzictwa kulturowego" (s. 406). Opracowanie jest godne uwagi ze względu na współpracę przedstawicieli różnych dyscyplin. Cmentarz jest tu nie tylko miejscem do zadumy, przywracania pamięci, ale także elementem dziedzictwa kulturowego. 
Tom wzbogacają refleksje uczestników różnych działań lokalnych w zakresie edukacji regionalnej i międzykulturowej. Do takich należy komunikat Urszuli Namiotko (Doświadczanie edukacji regionalnej w przestrzeni pogranicza na przyktadzie programu Klasa Dziedzictwa Kulturowego, s. 409-418). To interesujący zapis, refleksji i przeżyć związanych z udziałem Autorki w projekcie z zakresu edukacji regionalnej na obszarze, zróżnicowanym kulturowo i etnicznie, pogranicza polsko-litewskiego realizowanym w duchu edukacji międzykulturowej - projekcie Klasa Dziedzictwa Kulturowego, który analizuje po latach. Dobrze wpisuje się w część tomu poświęconą praktykowaniu edukacji międzykulturowej, dzięki temu Czytelnik ma okazję do poznania ciekawych form działalności regionalnej w Sejnach i Krasnogrudzie. Natomiast doniesienie Emilii Jakubowskiej (Edukacja regionalna na Kurpiowszczyźnie, s. 419-424) pozwala na poznanie wybranych przykładów działań szkół instytucji kulturalno-oświatowych, w obszarze edukacji regionalnej na Kurpiowszczyźnie i udowodnienie tezy, że edukacja regionalna może być interesująca dla młodego pokolenia, jeśli jest realizowana poprzez atrakcyjne formy i dotyczy ciekawych spraw. Bogactwo form kultury regionalnej może źródłem nowych rozwiązań i pomysłów oraz powodem do dumy dla mieszkańców regionu.

Książkę zamyka bardzo aktualne opracowanie Magdy Prusinowskiej ( $E d u$ kacja międzykulturowa wobec polityki migracyjnej Unii Europejskiej, s.425-440). Autorka, odwołując się do prac W. Rabczuka, analizuje konsekwencje polityki migracyjnej Unii Europejskiej dla edukacji międzykulturowej i odwrotnie. Analizuje podstawowe pojęcia związane z migracjami oraz politykę migracyjną krajów UE, w tym Polski. Akcentuje szanse rozwoju edukacji międzykulturowej w zależności od prowadzonej polityki migracyjnej przez UE. Należy zgodzić się z Autorką, że „edukacja międzykulturowa zarówno na poziomie uniwersyteckim, jak i w szkołach nie może pomijać tak istotnych zagadnień, jakimi są uchodźstwo i polityka migracyjna w obszarze uchodźstwa" (s. 437).

Teksty zostały bardzo starannie przygotowane przez redaktorów do druku. Każdy tekst jest opatrzony przypisami (często rozbudowanymi) oraz stosowną bibliografią i pracami ściśle związanymi z tekstem, do których Autorzy odwołują się w dużej mierze w swoich opracowaniach.

To wartościowy tom, który będzie przydatny dla nauczycieli i teoretyków regionalizmu oraz edukacji międzykulturowej, a także dla studentów kierunków humanistycznych i społecznych i będzie pożądany przez wielu w podręcznym księgozbiorze. 